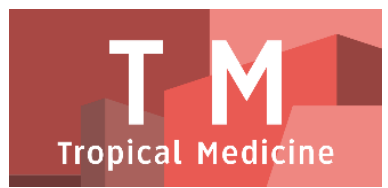

PAPER - OPEN ACCESS

\title{
Aktivitas Antioksidan Dari Ekstrak Etanol Herba Poguntano (Picria Fel-Terrae Lour.) Secara In Vitro
}

Author : Nevi Hayati Utami

DOI $\quad: 10.32734 /$ tm.v1i1.77

Paper Page : $218-223$

Volume 1 Issue 1 - 2018 TALENTA Conference Series: Tropical Medicine (TM)

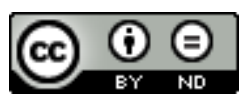

This work is licensed under a Creative Commons Attribution-NoDerivatives 4.0 International License.

Published under licence by TALENTA Publisher, Universitas Sumatera Utara
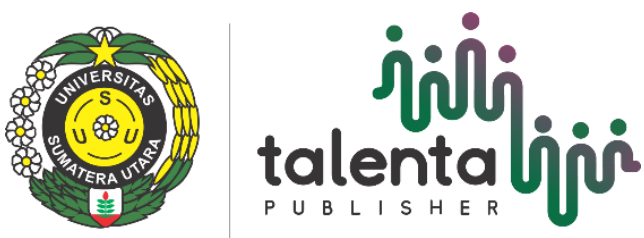


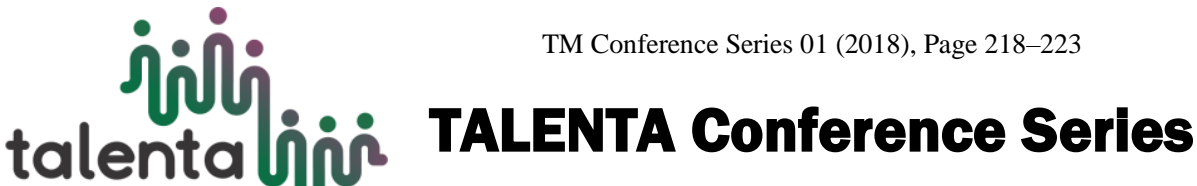 \\ Available online at https://talentaconfseries.usu.ac.id
}

\section{Aktivitas Antioksidan Dari Ekstrak Etanol Herba Poguntano (Picria Fel-Terrae Lour.) Secara In Vitro}

\author{
Nevi Hayati Utami ${ }^{\mathrm{a}, *}$, Suryadi Achmad ${ }^{\mathrm{a}}$, Panal Sitorus ${ }^{\mathrm{a}}$ \\ ${ }^{a}$ Fakultas Farmasi, Universitas Sumatera Utara, Medan 20155, Indonesia \\ nevi_hayatiutami@yahoo.co.id
}

\begin{abstract}
Abstrak
Latar Belakang: Antioksidan adalah senyawa yang mampu menangkal atau meredam efek negatif oksidan dalam tubuh, bekerja dengan cara mendonorkan satu elektronnya kepada senyawa yang bersifat oksidan sehingga aktivitas senyawa oksidan tersebut dapat dihambat. Herba poguntano (Picria fel-terrae Lour.) digunakan sebagai obat antidiabetes dan telah dilaporkan mengandung senyawa kimia yang terdiri dari alkaloid, saponin, flavonoid, dan polifenol yang merupakan metabolit sekunder yang bersifat antioksidan. Tujuan Penelitian: Penelitian ini bertujuan untuk mengetahui aktivitas antioksidan serta mengetahui kandungan fenolat dan flavonoid total dari ekstrak etanol herba poguntano. Metode Penelitian: Ekstrak diperoleh secara maserasi dengan pelarut etanol 96\%, lalu dipekatkan dengan alat rotary evaporator hingga didapatkan ekstrak kental. Ekstrak diuji dengan metode pemerangkapan radikal bebas DPPH (1,1-diphenyl-2-picrylhydrazyl) serta mengukur kandungan fenolat total dan flavonoid total dengan mengukur absorbansi menggunakan spektrofotometri uv-vis yang diinkubasi berturut-turut selama 60, 90 dan 40 menit pada panjang gelombang 516, 775 dan $432 \mathrm{~nm}$. Hasil: Hasil pengukuran aktivitas antioksidan dengan metode pemerangkapan radikal bebas DPPH dari ekstrak etanol herba poguntano menunjukkan kekuatan antioksidan dalam kategori sangan kuat dengan nilai IC50 21.79 ppm dan kuersetin menunjukkan kekuatan antioksidan dalam kategori sangat kuat dengan nilai IC50 4.9 ppm. Hasil pengukuran kandungan fenolat total dengan metode Folin-Ciocalteau menunjukkan angka $66.29 \mathrm{mg}$ GAE/g ekstrak serta hasil pengukuran kandungan flavonoid total menunjukkan angka $19.26 \mathrm{mg}$ QE/g ekstrak. Kesimpulan: Ekstrak etanol herba poguntano mempunyai aktivitas antioksidan dengan kategori sangat kuat serta memiliki kandungan fenolat total yang tinggi dibandingkan dengan kandungan flavonoid total..
\end{abstract}

Kata Kunci: Aktivitas Antioksidan, Herba Poguntano (Picria Fel-Terrae Lour.), DPPH, Kandungan Fenolat Total, Kandungan Flavonoid Total

\section{Pendahuluan}

Antioksidan adalah zat penghambat reaksi oksidasi akibat radikal bebas yang dapat menyebabkan kerusakan asam lemak tak jenuh, membran sel, pembuluh darah, DNA, dan jaringan lipid sehingga menimbulkan penyakit. Suatu tanaman dapat memiliki aktivitas antioksidan apabila mengandung senyawa yang mampu menangkal radikal bebas seperti fenol dan flavonoid [11]. Radikal bebas adalah molekul yang mempunyai satu atau lebih elektron tidak berpasangan, sifatnya sangat labil dan sangat reaktif sehingga dapat menimbulkan kerusakan pada komponen sel seperti DNA, lipid, protein, dan karbohidrat. Peranan antioksidan sangat penting dalam menetralkan dan menghancurkan radikal bebas yang dapat menyebabkan kerusakan sel dan juga merusak biomolekul di dalam tubuh yang akhirnya dapat memicu terjadinya penyakit degeneratif [9].

Sumber-sumber antioksidan dapat berupa antioksidan alami maupun sintetik. Industri makanan dan obat-obatan mengembangkan antioksidan alami dan mencari sumber-sumber antoksidan alami baru [10]. Salah satu tumbuhan 
yang digunakan adalah tumbuhan poguntano (Picria fel-terrae Lour.), yang telah digunakan sebagai obat kolik (mulas mendadak dan hebat), malaria, diuretik, demam, amenorrhea, dan gangguan pada kulit [4]. Di Cina Selatan poguntano digunakan untuk pengobatan demam, infeksi herpes, kanker dan inflamasi [13]. Poguntano (Picriafelterrae Lour.), oleh masyarakat Desa Tiga Lingga, Kabupaten Dairi, Provinsi Sumatera Utara dikenal dengan nama pugun tanoh, pugun tana dan pagon tanoh serta digunakan sebagai obat untuk mengobati berbagai macam penyakit seperti rematik, asam urat dan diabetes [1]. Selain itu, poguntano berkhasiat sebagai penghilang rasa sakit di badan, meningkatkan daya tahan tubuh, bahkan sebagai anti aging agar kelihatan awet muda [2].

Pengujian antioksidan terhadap herba poguntano (Picriafel-terrae Lour.) yang diduga potensial dalam menghasilkan bahan-bahan antioksidan dapat dilakukan dengan menggunakan metode efek pemerangkapan radikal bebas DPPH (1,1-diphenyl-2-picryhydrazil), metode Folin-Ciocalteu (kandungan fenolat total) dan metode kolorimetri (kandungan flavonoid total). Metode ini dilakukan karena mudah dilakukan dan hasilnya mudah didapatkan serta diduga pada herba poguntano terdapat golongan senyawa yang bersifat sebagai antioksidan seperti fenol dan flavonoid.

\section{Bahan dan Metode}

Sampel yang digunakan adalah herba poguntano (Picriafel-terrae Lour.). Bahan kimia yang digunakan yaitu: Aluminium klorida (AlCl3), DPPH (Sigma), kuersetin, Foin-Ciocalteu, Natrium karbonat (Na2CO3), Natrium asetat (CH3COONa).

Larutan DPPH 0,5 mM (konsentrasi $200 \mathrm{ppm}$ ) dipipet sebanyak $5 \mathrm{ml}$, kemudian dimasukkan ke dalam labu tentukur $25 \mathrm{ml}$, lalu dicukupkan dengan metanol sampai garis tanda (konsentrasi $40 \mathrm{ppm}$ ) [3]. Larutan tersebut dihomogenkan dan diukur serapannya pada panjang gelombang 400-800 nm yang merupakan panjang gelombang sinar tampak [1].

Pembuatan kontrol positif dan larutan uji EEHP (ekstrak etanol herba poguntano) metode DPPH dilakukan dengan cara $1 \mathrm{mg}$ serbuk kuersetin ditimbang, dimasukkan ke dalam labu tentukur $10 \mathrm{ml}$ dilarutkan dengan metanol lalu volumenya dicukupkan sampai garis tanda (konsentrasi $100 \mathrm{ppm}$ ). Larutan induk dipipet sebanyak 0,31 ml; 0,62 $\mathrm{ml} ; 1,25 \mathrm{ml} ; 2,50 \mathrm{ml}$; ke dalam labu ukur $25 \mathrm{ml}$ untuk mendapatkan konsentrasi larutan uji 1,25 ppm, 2,5 ppm, 5 ppm, 10 ppm. EEHP 25 gram ditimbang, dimasukkan ke dalam labu tentukur $25 \mathrm{ml}$ dilarutkan dengan metanol lalu volumenya dicukupkan sampai garis tanda (konsentrasi $1000 \mathrm{ppm}$ ). Konsentrasi ditetapkan setelah dilakukan beberapa orientasi. Larutan induk dipipet sebanyak $0,16 \mathrm{ml} ; 0,31 \mathrm{ml} ; 0,625 \mathrm{ml}$ dan 1,25 ml ke dalam labu ukur 25 $\mathrm{ml}$ untuk mendapatkan konsentrasi larutan uji 6,25 ppm, 12,5 ppm, $25 \mathrm{ppm}, 50 \mathrm{ppm}$, kemudian ke dalam masingmasing labu tentukur dari larutan kuersetin dan uji EEHP ditambahkan 5 ml larutan DPPH 0,5 mM (konsentrasi 200 ppm) lalu volumenya dicukupkan dengan metanol sampai garis tanda. Diamkan selama 60 menit, lalu diukur serapannya menggunakan spektrofotometer UV-Vis pada panjang gelombang yang diperoleh.

\subsection{Penentuan Kandungan Fenolat Total (Metode Folin-Ciocalteau)}

Pembuatan larutan asam galat sebagai standar dan larutan uji EEHP dilakukan dengan cara ditimbang 5 mg asam galat kemudian dilarutkan dengan methanol hingga $10 \mathrm{ml}$ (konsentrasi $500 \mathrm{ppm}$ ). Dipipet 2,5 ml dari setiap konsentrasi 500 ppm, 250 ppm, 125 ppm, 62,5 ppm, 31,25 ppm, 15,625 ppm kemudian dilarutkan dengan methanol hingga $5 \mathrm{ml}$. EEHP ditimbang $10 \mathrm{mg}$, kemudian dilarutkan dengan methanol hingga $10 \mathrm{ml}$ (konsentrasi $1000 \mathrm{ppm}$ ). Masing-masing konsentrasi dari larutan standar dan larutan uji dipipet 0,1 ml, kemudian ditambahkan 7,9 ml akuades, 0,5 ml Folin-Ciocalteau, divortex selama \pm 1 menit, serta ditambahkan 1,5 ml natrium karbonat (Na2CO3) 20\%, lalu diinkubasi selama 90 menit. Diukur panjang gelombang maksimum dari larutan standar (konsentrasi 500 ppm), lalu dilakukan pengukuran kurva kalibrasi. Absorbansi larutan uji diukur terhadap kalibrasi asam galat pada $775 \mathrm{~nm}$ secara spektrofotometri UV-Vis. Konsentrasi fenol dalam larutan uji dihitung dari plot kalibrasi dan dinyatakan sebagai mg asam galat setara dengan $\mathrm{mg} / \mathrm{g}$ dari sampel. 


\subsection{Penentuan kandungan flavonoid total (metodekolorimetri)}

Pembuatan larutan kuersetin sebagai standar dan larutan uji EEHP ditimbang $1 \mathrm{mg}$ kemudian dilarutkan dengan methanol hingga $10 \mathrm{ml}$ (konsentrasi 100 ppm). Dipipet 2,5 ml darisetiap konsentrasi 100 ppm, 50 ppm, 25 ppm, 12,5 ppm, 6,25 ppm, kemudian dilarutkan dengan methanol hingga5 ml. EEHP ditimbang $25 \mathrm{mg}$ dilarutkan dengan methanol hingga $25 \mathrm{ml}$ (konsentrasi $1000 \mathrm{ppm}$ ). Dipipet $2 \mathrm{ml}$ larutan uji EEHP, kemudian ditambahkan methanol hingga $10 \mathrm{ml}$ (konsentrasi $300 \mathrm{ppm}$ ). Dari masingmasing konsentrasi larutan standar dan larutan uji dipipet $2 \mathrm{ml}$, kemudian ditambahkan $0,1 \mathrm{ml}$ aluminium klorida (AlCl3) 10\%, 0,1 ml natrium asetat (CH3COONa), serta ditambahkan 2,8 ml akuades, lalu diinkubasi selama 40 menit. Diukur panjang gelombang maksimum dari larutan standar (konsentrasi 100 ppm), lalu dilakukan pengukuran kurva kalibrasi. Absorbansi larutan uji diukur terhadap kalibrasi kuersetin pada $432 \mathrm{~nm}$ secara spektrofotometri UV-Vis. Konsentrasi flavonoid dalam sampel uji yang dihitung dari plot kalibrasi dan dinyatakan sebagai kuersetin setara mg/g sampel.

\section{Hasil dan Pembahasan}

Aktivitas antioksidan dengan metode DPPH (1,1-diphenyl-2-picrylhydrazyl). Berdasarkan hasil penelitian, diperoleh data sebagai berikut:

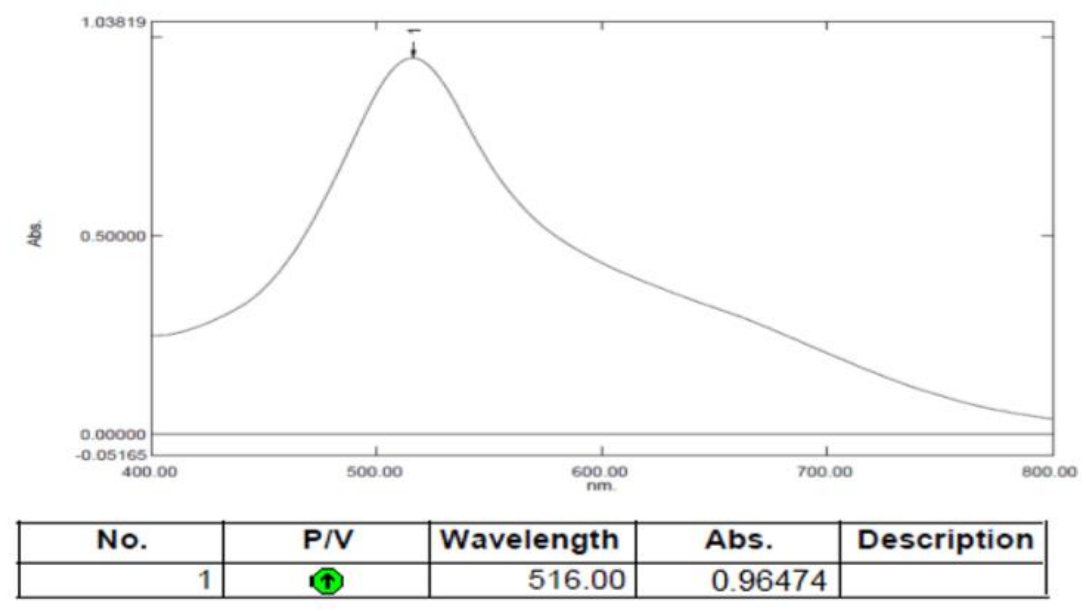

Fig. 1. Spektrum Serapan Maksimum DPPH (40ppm)

Table. 1. Hasil Persamaan Regresi Linier dan Hasis Analisis IC $_{50}$ yang diperoleh dari EEHP dan Kuersetin

\begin{tabular}{lll}
\hline Larutan Uji & Persamaan Regresi & $\mathrm{IC}_{50}(\mathrm{ppm})$ \\
\hline EEHP & $\mathrm{Y}=1,85656 \mathrm{x}+9.5035$ & 21,81 \\
Kuersetin & $\mathrm{Y}=9.05540 \mathrm{x}+5.1282$ & 4.96 \\
\hline
\end{tabular}

Tabel1 diatas diketahui bahwa EEHP menunjukkan aktivitas antioksidan kategori sangat kuat dengan nilai IC50 sebesar 21,81 ppm dan kuersetin memiliki aktivitas antioksidan yang sangat kuat dengan nilai IC50 sebesar 4,96 ppm. Molyneux (2004), menyatakan bahwa suatu zat mempunyai sifat antioksidan bila nilai IC50 kurang dari 200 ppm. Pengukuran fenolat total (metode Folin-Ciocalteu) dari larutan uji EEHP, serapan maksimum serta kurva kalibrasi asam galat dengan penambahan reagen Folin-Ciocalteau, Na.Karbonat, spektrofotometri UV-Visibel. Data yang diperoleh adalah: 


\begin{tabular}{|r|c|r|r|r|}
\hline No. & P/V & Wavelength & Abs. & Description \\
\hline 1 & + & 775.00 & 0.44434 & \\
\hline 2 & 0 & 470.50 & 0.21619 & \\
\hline
\end{tabular}

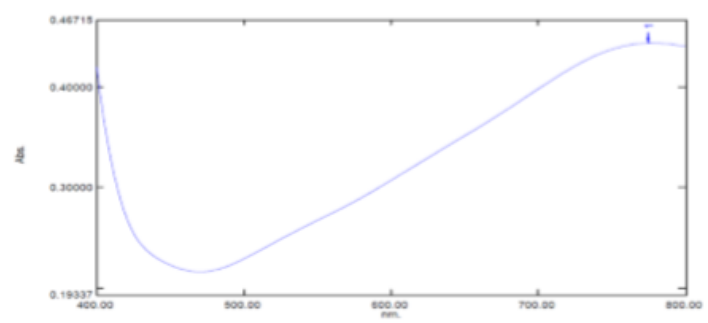

Fig. 2. Serapan Maksimum Asam Galat 500ppm secara spektofotometri visibel dan Kurva Standar Asam Galat

Table. 2. Kandungan Fenolat Total dari Ekstrak Etanol Herba Poguntano (EEHP)

\begin{tabular}{llccc}
\hline $\begin{array}{l}\text { Larutan } \\
\text { Uji }\end{array}$ & $\begin{array}{l}\text { Konsentrasi } \\
(\mathrm{ppm})\end{array}$ & Absorbansi & $\begin{array}{l}\text { Kadar Fenol Total } \\
(\mathrm{mg} \mathrm{GAE} / \mathrm{g})\end{array}$ & $\begin{array}{l}\text { Rata-Rata Kadar } \\
\text { Fenol Total }(\mathrm{mg} \\
\text { GAE/g) }\end{array}$ \\
\hline \multirow{3}{*}{ EEHP } & \multirow{2}{*}{1000} & 0,09741 & 67,0632 & \\
& & 0,09602 & 65,7258 & 66,2933 \\
& & 0,09604 & 65,7450 & \\
& & 0,09656 & 66,2453 & \\
& & 0,09702 & 66,6879 & \\
\hline
\end{tabular}

Pengukuran flavonoid total (metode kolorimetri) dari larutan uji EEHP, serapan maksimum kuersetin dengan penambahan reagen aluminium klorida $(\mathrm{AlCl} 3)$, natrium asetat $(\mathrm{CH} 3 \mathrm{COONa})$, serta air pada konsentrasi $100 \mathrm{ppm}$ menggunakan spektrofotometri UV-Visibel. Data yang diperoleh adalah:

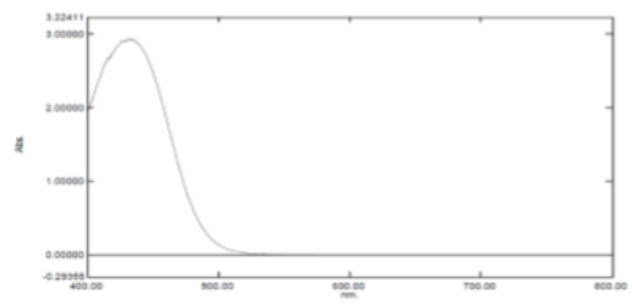

\begin{tabular}{|r|c|r|c|c|}
\hline No. & P/V & Wavelength & Abs. & Description \\
\hline 1 & $\Phi$ & 432.00 & 2.93097 & \\
\hline
\end{tabular}

Fig. 3. Serapan maksimum kuersetin 100 ppm secara spektrofotometri visible 


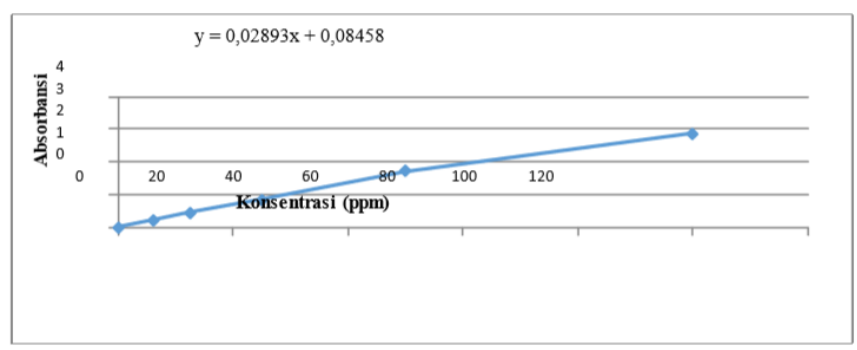

Fig. 4. Kurva standar Kuersetin

Table. 3. Kandungan Flavonoid Total dari Ekstrak Etanol Herba Poguntano (EEHP)

\begin{tabular}{lcccc}
\hline $\begin{array}{l}\text { Larutan } \\
\text { Uji }\end{array}$ & $\begin{array}{l}\text { Konsentrasi } \\
(\mathrm{ppm})\end{array}$ & Absorbansi & $\begin{array}{l}\text { Kadar Flavonoid } \\
\text { Total }(\mathrm{mg} \text { QE/g) }\end{array}$ & $\begin{array}{l}\text { Rata-Rata Kadar } \\
\text { Flavonoid Total } \\
(\mathrm{mg} \text { QE/g) }\end{array}$ \\
\hline \multirow{3}{*}{ EEHP } & \multirow{2}{*}{1000} & 0,25294 & 19,3021 & \\
& & 0,25304 & 19,3133 & 19,2659 \\
& & 0,25284 & 19,2905 & \\
& & 0,25204 & 19,1988 & \\
& & 0,25227 & 19,2251 & \\
\hline
\end{tabular}

Senyawa fenol diketahui memiliki aktivitas antioksidan. Senyawa fenol merupakan metabolit sekunder yang daat menjaga kesehatan tubuh manusia. Adanya kandungan kimia pada tumbuhan seperti fenol, flavonoid dan tanin, mengindikasikan kemungkinan adanya aktivitas antioksidan dan aktivitas antioksidan ini dapat membantu mencegah terjadinya penyakit melalui aktivitas penangkalan radikal bebas [3].

\section{Kesimpulan}

Ekstrak etanol herba poguntano mempunyai aktivitas antioksidan dengan kategori sangat kuat serta memiliki kandungan fenolat total yang tinggi dibandingkan dengan kandungan flavonoid total. Penulis berharap agar peneliti selanjutnya untuk melakukan uji aktivitas farmakologi dari berbagai fraksi.

\section{Referensi}

[1] Gandjar, I.G., dan Abdul Rohman. (2007). Kimia Analisis Farmasi. Pustaka Pelajar, Yogyakarta, Indonesia.

[2] Kuncahyo, L., dan Sunardi. (2007). Uji aktivitas Antioksidan Ekstrak Belimbing Wuluh (Averrhoa bilimbi, L.) terhadap 1,1-diphenyl-2picryhydrazil (DPPH). Seminar Nasional Teknologi 2007.

[3] Mardawati, E., Achyar, C.S., dan Marta, H. (2008). Kajian Aktivitas Antioksidan Ekstrak Kulit Manggis (Garcinia mangostana L.) dalam Rangka Pemanfaatan Limbah Kulit Manggis di Kecamatan Puspahiang Kabupaten Tasikmalaya. Laporan Akhir Penelitian Peneliti Muda (LITMUD) UNPAD, Semarang, Indonesia.

[4] Perry, L.M. (1980). Medicinal Plants of East and Southeast Asia. The MIT Press, London, England, halaman 384.

[5] Rafi M., Niken, W., Elly, S., dan Latifah, K.D. (2013). Aktivitas Antioksidan, Kadar Fenol dan Flavonoid Total dari Enam Tumbuhan Obat Indonesia. Traditional Medicine Journal 18 (1), 2934.

[6] Ramadhan, P. (2015). Mengenal Antioksidan. Graha Ilmu, Yogyakarta, Indonesia.

[7] Rohman, A., dan Sugeng, R. (2005). Daya antioksidan Ekstrak Etanol Daun Kemuning (Muraya paniculata (L) Jack) secara in vitro. Majalah farmasi Indonesia 16 (3), 136-140. 
[8] Rosidah, Yam, M.F., Sadikun, A., dan Asmawi, M.Z. (2008). Antioxidant Potential of Gynura procumbens. Pharmaceutical Biology 46 (9), 616-625.

[9] Soekmanto, A., Yatri, H., dan Partomuan, S. (2007). Kandungan Antioksidan dari Beberapa Bagian Tanaman Mahkota Dewa (Phaleria macrocarpa (Scheff) Boerl.). (Thymelaceae). Biodiversitas 8 (2), 92-95.

[10] Takashi, M., dan Takayumi, S. (1997). Antioxidant Activity of Natural Compound Found in Plants. Journal of Agriculture and Food Chemistry. 45.

[11]Widyastuti, N. (2010). Pengukuran Aktivitas Antioksidan dengan Metode Cuprac, DPPH, dan Frap serta Korelasinya dengan Fenol dan Flavonoid pada Enam Tanaman. Skripsi. Bogor: Fakultas Matematika dan Ilmu Pengetahuan Alam IPB.

[12]Zhong, S.Q., Zhang, B.N., dan Huang, F.X. (1979). An Antitumor Herb Cucao. Chin Tradit Herb Drugs Lett 3, China, halaman $45-46$.

[13]Zou, J.M., Wang, L.S., Niu, X.M., Sun, H.D., dan Guo, Y.J. (2005). Phenylethanoid Glycosides from Picria fel-terrae Lour. Journal of Integrative Plant Biology 47 (5), 632-636.

[14]Zuhra, F.C., Juliati, T., dan Herlince, S., (2008). Aktivitas Antioksidan Senyawa Flavonoid dari Daun Katuk (Saurous androgunus (L) Merr.). Journal Biologi Sumatera 3 (1), 7-10. 